\title{
IMPACT OF COMPOST TEA IN CONTROLLING CHOCOLATE LEAF SPOT DISEASE AND SOIL MICROORGANISMS' DENSITY IN FABA BEAN (VICIA FABA L.)
}

\author{
Haba A.K. Ibrahim \\ Department of Soil Fertility and Microbiology, Desert Research Center, \\ El-Matareya, Cairo, Egypt \\ E-mail: hebaahmed286@hotmail.com
}

$\mathrm{T}$ his study was conducted to determine the effect of compost tea (CT) as an alternative biological fungicide for controlling chocolate leaf spot disease in faba bean, with different application methods, in addition to the effects on soil biota, yield and growth parameters of faba bean. Compost tea as a foliar spray (F) and as a soil drench (SD), significantly decreased disease severity, while increased it by seed soaking (SS). Soil drenching, significantly increased yield weight, number of leaves, pods and seeds and weight of seeds. Soil microorganisms were enhanced significantly with the foliar spray treatment. Peroxidase enzyme (PO) increased by $200 \%$ by all methods. Polyphenol oxidase enzyme (PPO) reached $1411 \%$ by integrated treatment with $\mathrm{F}, \mathrm{SD}$ and $\mathrm{SS}$ at $50 \%$ compost tea concentration. Total phenols reached $120 \%$ by SD at $25 \%$. It can be concluded that compost tea after brewing for six days, can control chocolate leaf spot disease in broad bean. In addition, it improves almost all yield parameters, plant disease resistance against the fungal pathogen and enhanced soil microbs.

Keywords: chocolate leaf spot, compost tea, fungal pathogen, Vicia faba, soil microorganisms

Synthetic fungicides are widely used in agriculture to control fungal plant diseases. Most of them are highly toxic (Zaker, 2016), sometimes carcinogenic for humans and wild animals, nonbiodegradable, and long-term environmental pollutants. They are lack prolonged efficacy because of the development of resistance in plant pathogens (Daoubi et al., 2005). Efforts are going on to use organic products as alternatives to agrochemicals for plant protection.

Compost tea is an organic extract produced from composted organic matter and containing a diversity of naturally occurring microbes and soluble macronutrients. Previous studies have mentioned that compost extracts helped to enhance plant health quality, yield and nutritional traits (Kim et al., 
2015). Compost tea is a possible alternative to synthetic chemical fungicides because of its antimicrobial activities (Siddiqui et al., 2009 and Seddigh and Kiani, 2018). Microorganisms in compost teas may act through one or more biological control mechanisms, competing for nutrients and/or space (AlMughrabi et al., 2008). Bacterial extracts, for bacteria isolated from compost tea, i.e. Brevibacterium linens and Bacillus subtilis contain antifungal compounds, indicating that antibiosis is the main mechanism of action (On et al., 2015). Compost teas are safe for health and the environment, relatively cheap and advantageous for agronomy.

Faba bean (Vicia faba L.) is one of the most important legume crops in Egypt as a source of food for both humans and animals and it improves soil fertility through nitrogen fixation. It is attacked by many foliar diseases such as chocolate spot (Botrytis fabae and Botrytis cinerea), which causes considerable losses in the yield and its component. Chocolate spot disease is a major problem for faba bean plants, because it infects and destroys the entire canopy of plants, limiting photosynthetic activity and affecting the productivity (Eisa et al., 2006).

The present work was designed to investigate the potential of compost tea to reduce chocolate leaf spot disease in broad bean caused by $B$. fabae, its possibility to induce resistance, and at the same time estimate the effect of compost tea on soil microorganisms and yield parameters of faba bean plants.

\section{MATERIALS AND METHODS}

\section{Compost Source}

Commercial compost from El-Arabiya-for-Organic-Fertilizer Factory was used. Compost was produced from a mixture of agricultural and animal wastes by aerobic method.

\section{Chemical Analysis of Compost}

Commercial compost was analyzed (Table 1) by unit of soil fertility, Department of Soil fertility and Microbiology, Desert Research Center.

Table (1). Elemental analysis of compost.

\begin{tabular}{rrrrrrrc}
\hline \multicolumn{7}{c}{ Major elements } \\
\hline $\mathbf{C} / \mathbf{N}$ & & $\mathbf{\%}$ & & & \multicolumn{2}{c}{$\mathbf{m g} / \mathbf{g}$} \\
\hline & $\mathbf{N}$ & $\mathbf{P}$ & $\mathbf{K}$ & $\mathbf{F e}$ & $\mathbf{M n}$ & $\mathbf{Z n}$ & $\mathbf{C u}$ \\
\hline 16.8 & 1.46 & 0.78 & 1.12 & 0.325 & 0.146 & 0.0785 & 0.0354 \\
\hline
\end{tabular}

\section{Source of Pathogen}

Isolate of $B$. fabae was obtained from Department of Legume and Forage Crop Diseases, A.R.C, Giza, Egypt. The growing colonies were 
transferred to new plates of faba bean dextrose agar (FDA) and incubated at $18-20^{\circ} \mathrm{C}$.

\section{Compost Tea Preparation}

Aerated CT was produced by mixing mature commercial compost with distilled water at a ratio of $1: 5(\mathrm{w} / \mathrm{v})$ and supplemented with $2 \%$ molasses for microbial growth stimulation. The entire contents were continuously aerated at room temperature with a fish tank bubbling pump. For further application, CT was poured through cheesecloth then cotton in lab experiments, sterilized by passing through $0.2 \mu \mathrm{m}$ filter and stored in freezer until use.

\section{Antifungal Activity of Compost Tea}

Assay of antifungal activity by $\mathrm{CT}$ depended on the growth retardation level of the pathogen in growth medium containing CT. Double strength potato dextrose agar (PDA) medium was supplemented with faba bean leaf extract for growing tested pathogen (B. fabae). While still warm, medium was combined with an equal volume of filter sterilized CT, and after mixing, was poured into plates. Tested pathogen was inoculated in plate's central points. At the same time, it was inoculated in the same manner in single strength, CT- free medium plates. Plates were incubated at $26^{\circ} \mathrm{C}$. Incubation was over when mycelium growth reached the substantial size either in the control or in the test plates, whichever came first, and the diameter of the colonies were measured. Antifungal activity in percent was determined against untreated control (Ibrahim, 2008).

\section{Plant Materials}

Faba been seeds (cv. Giza 429) were obtained from Legume Crops Research Department, Agricultural Research Center, Giza, Egypt, were used to investigate the effect of compost tea against $B$. fabae with different application methods.

\section{Application of Compost Tea on Faba Bean Infected Plants}

CT after brewing for six days (as an effective age for disease suppression from lab experiments results), and plastic bags $(30 \mathrm{~cm}$ diameter, $40 \mathrm{~cm}$ height), each filled with $11 \mathrm{~kg}$ of un-sterilized clay soil were used in this experiment. Seven treatments of CT applied as follows:

Foliar spray (F)

Soil drench (SD)

Seed soaking (SS) Foliar spray + soil drench

Foliar spray + seed soaking

Foliar spray + soil drench + seed soaking

Three concentrations $(25 \%, 50 \%$ and $75 \%)$ of CT were used with all tested application methods. 
Faba beans (cv. Giza 429) were planted, mid-November 2013, at a rate of 5 seeds/bag. Twenty days after seeding, the plants were thinned to 3 seedlings/bag. Treatments of CT were applied as $\mathrm{F}$ at 40 days from sowing and one day before the artificial inoculation with $B$. fabae spore suspension. The suspension prepared by, flooded one single colony of $B$. faba in plate by $5 \mathrm{ml}$ sterilized distilled water, scraping the surface of the colony to release the spores, took up the water containing the released spores from the plate and transferred to a $5 \mathrm{~mL}$ sterilized $0.85 \% \mathrm{NaCl}$ solution containing $0.05 \%$ Tween 80 , vortexed the spore suspension for one minute to break any mycelium fragment, then gently with a pipette tip took the suspension to perform spore count by count chamber $\left(2.5 \times 10^{5}\right.$ conidia $/ \mathrm{ml}$ supplemented with $0.05 \%$ Tween 20 ). Bags inoculated with only $B$. faba spore suspension served as control treatment. For SD treatments CT was added directly, before seed sowing, to soil at a rate of $100 \mathrm{ml} / \mathrm{bag}$. Seed treatments were done by soaking faba bean seeds in CT concentrations for $24 \mathrm{~h}$ before seeding. All inoculated bags were covered with hyaline polyethylene sacs for $48 \mathrm{~h}$ as moist chambers (Mahmoud et al., 2012). The trial was designed as randomized complete block design (RCBD) with three triplicates for each treatment.

\section{Disease Severity}

Assay of disease severity was done according to the scale of Bernier et al. (1993). After fifteen-days post inoculation, assay was done as follows: $1=$ no disease symptoms or very small specks (highly resistant); $3=$ few small discrete lesions (resistant); $5=$ some coalesced lesion with some defoliation (moderately resistant); $7=$ large coalesced sporulating lesions, $50 \%$ defoliation and some dead plant (susceptible); $9=$ extensive lesions on leaves, stems and pods, severe defoliation, heavy sporulation, stem girdling, blackening and death of more than $80 \%$ of plants (highly susceptible). Chocolate spot disease severity \% was assessed according to the following formula,

Disease severity $\%=\Sigma(n \times v) \div 9 N \times 100$

Where, $(n)=$ Number of plants in each category; $(v)=$ Numerical values of symptoms category; $(N)=$ Total number of plants; $(9)=$ Maximum numerical value of symptom category.

\section{Yield and Growth Parameters}

Yield weight $(\mathrm{g})$, number of leaves, number of pods and dry seeds weight $(\mathrm{g})$ and number of seeds per plant were recorded after fifteen-day post inoculation with $B$. fabae and after 55 days from starting.

\section{Oxidative Enzymes Activities}

Peroxidase enzyme activity was measured as described by Chance and Maehly (1955). Polyphenol oxidase activity was assayed according to 
the method of Taneja and Sachar (1974). Enzyme activity was expressed as $\Delta 420$ and $\Delta 430 / \mathrm{min} / \mathrm{g}$ fresh weight, respectively. All crude leaf enzyme extract was prepared according to Patra and Mishra (1979).

The percentage of increase in PO and PPO activities were calculated using the following formula:

Increase $(\%)=$ Valueof treatment -

value of control/value of control $\times 100 \%$

\section{Total Phenols Assay}

From one of three replicates for each treatment, the tenth plant leaf was taken and used in extraction process according to the method of Simons and Ross (1971). Total phenols were calculated for each treatment as milligrams of catechol per one-gram fresh weight according to standard curve of catechol. The increase in total phenol content as percentage was calculated using the following formula:

Increase $(\%)=$ Value of treatment -

value of control/value of control $\times 100 \%$

\section{Total Microbial Count}

For all microbial investigations in soil, $1 \mathrm{~g}$ of soil was suspended in $10 \mathrm{ml}$ of sterilized water and stirred for half an hour. Then, serial dilutions were prepared, cultured, and enumerated by total plate counts in nutrient plate agar.

Media

- Potato dextrose agar

$\begin{array}{llll}\text { Glucose } & 20.0 \mathrm{~g} & \text { Agar } & 15.0 \mathrm{~g}\end{array}$

${ }^{*}$ Leaf extract $100 \mathrm{ml} \quad{ }^{* *}$ Potato infusion $1.0 \mathrm{~L}$

*Freshly plucked leaves of faba bean were washed and dried in the shade (35 days). Following washing and drying, leaves were ground in a domestic blende, then $5 \mathrm{~g}$ from the powder was added to $100 \mathrm{ml}$ of sterile distilled water, and boiled for $10 \mathrm{~min}$ in conical flasks. The extract filtered through Watman No.1. The final volume was $100 \mathrm{ml}$. ${ }^{* *}$ A portion of $300 \mathrm{~g}$ potatoes was peeled and diced. Five hundred $\mathrm{ml}$ distilled water was added, the mixture was boiled for $30 \mathrm{~min}$, filtered through cheesecloth and the final volume was adjusted to one liter.

\section{- Nutrient agar}

$\begin{array}{llll}\text { Glucose } & 10.0 \mathrm{~g} & \text { Peptone } & 10.0 \mathrm{~g} \\ \text { Yeast extract } & 5.0 \mathrm{~g} & \text { Agar } & 15.0 \mathrm{~g}\end{array}$

\section{Statistical Analysis}

Data were analyzed statistically in triplicates for the least significant difference (LSD). The LSD technique was used to test the differences between means at probability $<0.05$. 


\section{RESULTS AND DISCUSSION}

\section{Elemental Analysis of Compost}

The elemental analysis of compost showed that $\mathrm{C} / \mathrm{N}$ ratio was 16.8 ; $\mathrm{N}, \mathrm{P}$ and $\mathrm{K} \%$ were 1.46, 0.78 and 1.12, respectively, and $\mathrm{Fe}, \mathrm{Mn}, \mathrm{Zn}$ and $\mathrm{Cu}$ $\mathrm{mg} / \mathrm{g}$ were $0.325,0.146,0.0785$ and 0.0354 , respectively (Table 1 ).

\section{Antifungal Activity of Compost Tea}

Aerated CT was brewed for seven days. It was tested daily, in vitro, against fungus pathogen $B$. fabae. It showed antifungal activity towards the fungus after three days, and reached $100 \%$ inhibition after six days (Fig. 1 and 2). In these experiments, the antifungal activity increased with brewing time. Accumulation of soluble nutrients from compost to CT during brewing time enhanced beneficial microorganisms in tea (Ingham, 2005), which produce antimicrobial compounds. These microbial inhibitory substances accumulated by time and make the suppression effect of tea (Weltzien, 1991).

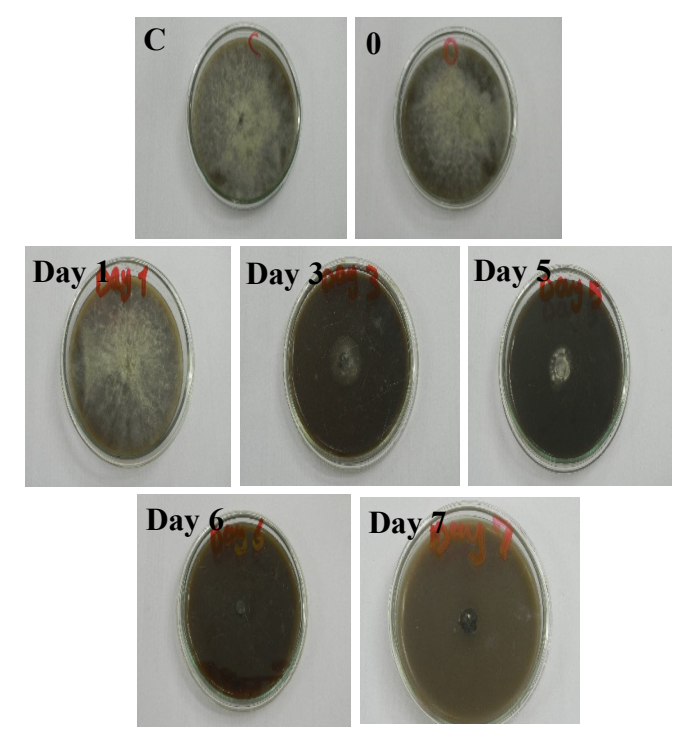

Fig. (1). Antifungal activity of aerated compost against Botrytis fabae in PDA containing CT, at zero day (0), one day (Day 1 ), three days (Day 3), five days (Day 5), six days (Day 6), seven days (Day 7) and PDA without $\mathrm{CT}$ as a control (C).

Egyptian J. Desert Res., 68, No. 1, 89-116 (2018) 


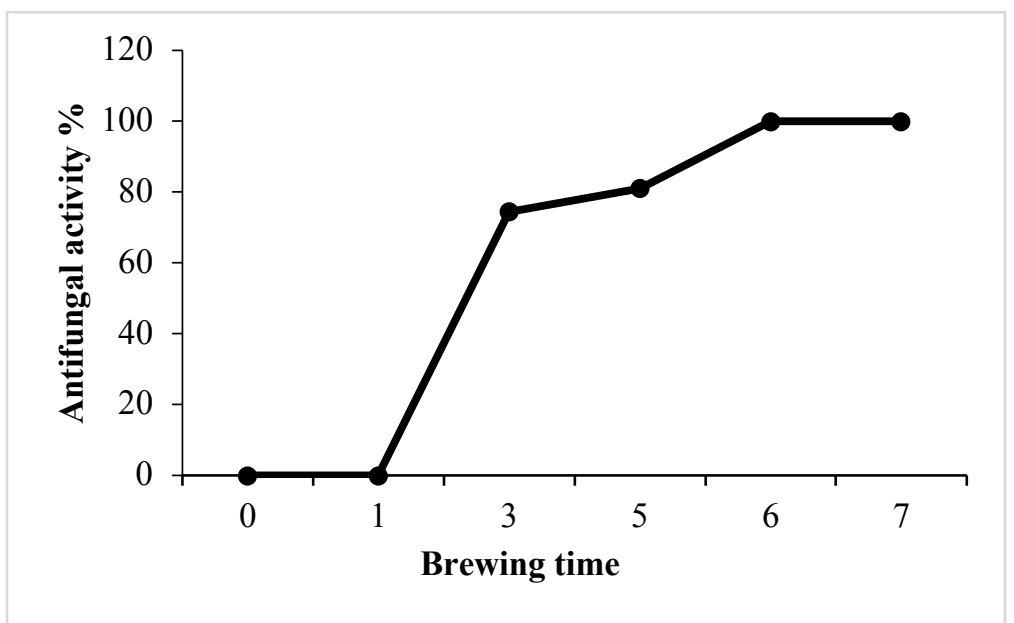

Fig. (2). Antifungal activity $\%$ of compost tea during brewing time.

\section{Effect of Compost Tea on Disease Severity}

After fifteen days of inoculation with $B$. fabae, F decreased disease severity the most (Table 2 and Fig. 3). Compost Tea at 50 and $75 \%$ concentrations, significantly decreased the chocolate spot disease severity by 59 and $50 \%$, respectively compared with control. In addition, SD treatment at 25 and $50 \% \mathrm{CT}$, significantly decreased disease severity. An integrated treatment with both methods, $\mathrm{F}$ and $\mathrm{SD}$ at $50 \% \mathrm{CT}$ decreased the disease severity, significantly, about $40 \%$ (Fig. 3). In contrary, SS increased disease severity. The application of CT to soils either can be categorized as induced suppression (Baker and Cook, 1974), by making conditions more favorable for the development of resident antagonists, or can be categorized as introduced suppression (Hornby, 1983) by adding antagonists to the soil.

The efficiency of CT in controlling disease severities was reported by several authors. In this respect, Al-Mughrabi (2007) revealed that, CT reduced severity by 29 and $27 \%$, when applied foliarly against late blight (Phytophthora infestans) of potato (Solanum tuberosum). In addition, CT as a SD significantly suppressed the severity of late blight foliar disease (Phytophthora infestans) in tomatoes and potatoes (Islam et al., 2013). Moreover, dollar spot disease (Sclerotinia homoeocarpa) can be controlled by CT (Hsiang and Tian, 2007). The authors suggested that, suppression by CT depend on having beneficial effects on soil microorganisms, and increase both of their diversity and number in the soil. On other hand, diseases, powdery mildew, Septoria leaf spot, and bacterial speck, incidence and severity, were insignificantly reduced by CT (McGrath, 2007). Possible reasons might be including that $\mathrm{CT}$ was ineffective including lack of appropriate organisms in compost, unsuitable recipe or brewing conditions, applications made at the wrong time of day and treatments needed earlier in crop development or perhaps included a seed treatment. 
Table (2). Effect of compost tea treatments and concentrations on disease severity $\%$ (DS \%).

\begin{tabular}{|c|c|c|c|c|}
\hline & \multicolumn{2}{|c|}{ Treatments } & \multirow{2}{*}{$\begin{array}{l}\text { DS\% } \\
50.62\end{array}$} & \multirow{2}{*}{$\begin{array}{r}\text { SD } \\
8.56\end{array}$} \\
\hline & \multirow{4}{*}{$\mathbf{F}$} & $25 \% \mathrm{CT}$ & & \\
\hline & & $50 \% \mathrm{CT}$ & 11.11 & 0.00 \\
\hline & & $75 \% \mathrm{CT}$ & 13.58 & 4.28 \\
\hline & & Mean & 25.10 & 22.13 \\
\hline & \multirow{4}{*}{ SD } & $25 \% \mathrm{CT}$ & 20.99 & 11.31 \\
\hline & & $50 \% \mathrm{CT}$ & 13.58 & 4.28 \\
\hline & & $75 \% \mathrm{CT}$ & 29.63 & 6.41 \\
\hline & & Mean & 21.40 & 8.03 \\
\hline & \multirow{4}{*}{ SS } & $25 \% \mathrm{CT}$ & 48.15 & 12.83 \\
\hline & & $50 \% \mathrm{CT}$ & 53.09 & 3.55 \\
\hline & & $75 \% \mathrm{CT}$ & 30.86 & 4.27 \\
\hline & & Mean & 44.03 & 11.67 \\
\hline & \multirow{4}{*}{$\mathbf{F}+\mathbf{S D}$} & $25 \% \mathrm{CT}$ & 25.93 & 4.35 \\
\hline & & $50 \% \mathrm{CT}$ & 16.05 & 4.28 \\
\hline & & $75 \% \mathrm{CT}$ & 34.57 & 18.32 \\
\hline & & Mean & 25.52 & 9.27 \\
\hline & \multirow{4}{*}{$\mathbf{F}+\mathbf{S S}$} & $25 \% \mathrm{CT}$ & 29.63 & 6.41 \\
\hline & & $50 \% \mathrm{CT}$ & 40.74 & 12.83 \\
\hline & & $75 \% \mathrm{CT}$ & 33.33 & 0.00 \\
\hline & & Mean & 34.57 & 5.66 \\
\hline & \multirow{4}{*}{$\mathbf{S D}+\mathbf{S S}$} & $25 \% \mathrm{CT}$ & 33.33 & 0.00 \\
\hline & & $50 \% \mathrm{CT}$ & 33.33 & 0.00 \\
\hline & & $75 \% \mathrm{CT}$ & 25.93 & 7.41 \\
\hline & & Mean & 30.86 & 4.27 \\
\hline & \multirow{4}{*}{$\mathbf{F}+\mathbf{S D}+\mathbf{S S}$} & $25 \% \mathrm{CT}$ & 40.74 & 12.83 \\
\hline & & $50 \% \mathrm{CT}$ & 25.92 & 12.83 \\
\hline & & $75 \% \mathrm{CT}$ & 33.33 & 0.00 \\
\hline & & Mean & 33.33 & 7.41 \\
\hline & \multicolumn{2}{|c|}{ Control } & 27.16 & 5.66 \\
\hline \multirow{3}{*}{$\begin{array}{l}\text { L.S.D. } \\
(5 \%)\end{array}$} & \multicolumn{2}{|c|}{ App. methods } & 2.64 & \\
\hline & \multirow{2}{*}{\multicolumn{2}{|c|}{$\begin{array}{c}\text { Concentrations } \\
\text { Interaction }\end{array}$}} & 1.51 & \\
\hline & & & 610.50 & \\
\hline
\end{tabular}

Egyptian J. Desert Res., 68, No. 1, 89-116 (2018) 


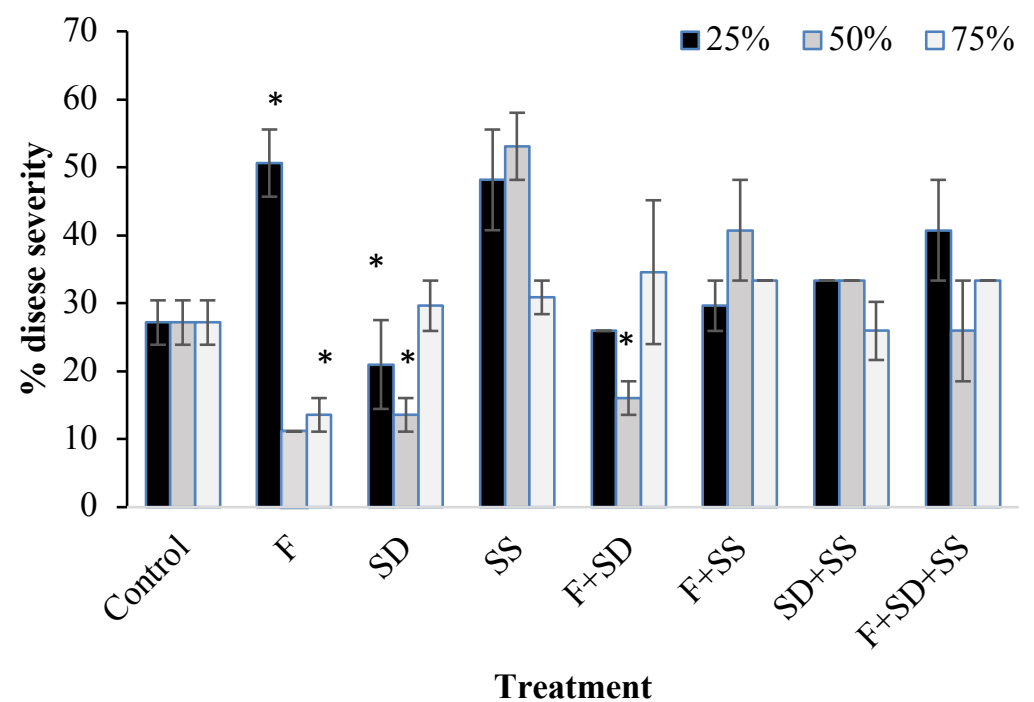

Fig. (3). Effect of compost tea treatments on disease severity \% (DS \%). (F) foliar spray, (SD) soil drench, (SS) seed soaking.

* Significant $(p<0.05)$

\section{Effect of Compost Tea on Yield Weight}

Compost tea has a role as a liquid biofertilizer, because it has a high nutrient value and rapid availability for plants. It has been found that CT contains nitrogen mainly as inorganic form like ammonia (Price and Duddles 1984 and Gross et al., 2007) and can provide nutrients instantly to the plants much like the chemical fertilizers. It is also boost the plant and soilenhancing activity of soil life, because it is rich in microorganisms that recycle organic matter. In this study, adding $\mathrm{CT}$ as a SD increased yield weight significantly; the increment was almost $200 \%$ at $25 \%$ CT concentration, and more than $100 \%$ at 50 and $75 \%$ CT concentrations (Table 3 and Fig. 4). These results are in agreement with El Hanafi (2005), who revealed that the application of $\mathrm{CT}$ to root zone showed a remarkable yield, and increased root growth significantly compared with control. In addition, Essah et al. (2013) mentioned that tuber yield in potato production was an optimum, with reduced or no fungicide application.

Yield weight increased significantly with some other concentrations within treatments, with $50 \% \mathrm{CT}$ as foliar, with $75 \% \mathrm{CT}$ as SS treatment, with $50 \% \mathrm{CT}$ as integrated foliar and SD treatment, with $75 \% \mathrm{CT}$ as integrated foliar and SS treatment, and with $75 \% \mathrm{CT}$ as integrated foliar, SD and SS treatment. 
Table (3). Effect of compost tea treatments and concentrations on yield weight.

\begin{tabular}{|c|c|c|c|c|}
\hline & \multicolumn{2}{|c|}{ Treatments } & \multirow{2}{*}{$\begin{array}{c}\begin{array}{c}\text { Yield } \\
\text { weight }\end{array} \\
19.69\end{array}$} & \multirow{2}{*}{$\begin{array}{r}\text { SD } \\
0.63\end{array}$} \\
\hline & \multirow{4}{*}{$\mathbf{F}$} & $25 \% \mathrm{CT}$ & & \\
\hline & & $50 \% \mathrm{CT}$ & 25.12 & 0.16 \\
\hline & & $75 \% \mathrm{CT}$ & 19.82 & 0.81 \\
\hline & & Mean & 21.54 & 3.29 \\
\hline & \multirow{4}{*}{ SD } & $25 \% \mathrm{CT}$ & 64.27 & 1.75 \\
\hline & & $50 \% \mathrm{CT}$ & 26.47 & 0.89 \\
\hline & & $75 \% \mathrm{CT}$ & 63.63 & 0.59 \\
\hline & & Mean & 51.46 & 21.65 \\
\hline & \multirow{4}{*}{ SS } & $25 \% \mathrm{CT}$ & 6.25 & 0.46 \\
\hline & & $50 \% \mathrm{CT}$ & 16.31 & 0.38 \\
\hline & & $75 \% \mathrm{CT}$ & 25.62 & 0.67 \\
\hline & & Mean & 16.06 & 9.69 \\
\hline & \multirow{4}{*}{$\mathbf{F}+\mathbf{S D}$} & $25 \% \mathrm{CT}$ & 16.18 & 1.22 \\
\hline & & $50 \% \mathrm{CT}$ & 25.20 & 0.81 \\
\hline & & $75 \% \mathrm{CT}$ & 21.04 & 1.40 \\
\hline & & Mean & 20.81 & 4.51 \\
\hline & \multirow{4}{*}{$\mathbf{F}+\mathbf{S S}$} & $25 \% \mathrm{CT}$ & 19.16 & 1.11 \\
\hline & & $50 \% \mathrm{CT}$ & 12.77 & 0.89 \\
\hline & & $75 \% \mathrm{CT}$ & 26.88 & 1.50 \\
\hline & & Mean & 19.60 & 7.06 \\
\hline & \multirow{4}{*}{$\mathbf{S D}+\mathbf{S S}$} & $25 \% \mathrm{CT}$ & 20.96 & 3.09 \\
\hline & & $50 \% \mathrm{CT}$ & 20.78 & 0.67 \\
\hline & & $75 \% \mathrm{CT}$ & 20.67 & 0.78 \\
\hline & & Mean & 20.80 & 0.15 \\
\hline & \multirow{4}{*}{$\mathbf{F}+\mathbf{S D}+\mathbf{S S}$} & $25 \% \mathrm{CT}$ & 16.75 & 0.75 \\
\hline & & $50 \% \mathrm{CT}$ & 13.86 & 0.97 \\
\hline & & $75 \% \mathrm{CT}$ & 28.13 & 1.04 \\
\hline & & Mean & 19.58 & 7.54 \\
\hline & \multicolumn{2}{|l|}{ Control } & 21.63 & 0.00 \\
\hline \multirow{3}{*}{$\begin{array}{l}\text { L.S.D. } \\
(5 \%)\end{array}$} & \multirow{3}{*}{\multicolumn{2}{|c|}{$\begin{array}{c}\text { App. methods } \\
\text { Concentrations } \\
\text { Interaction }\end{array}$}} & 1.66 & \\
\hline & & & 0.95 & \\
\hline & & & 6.65 & \\
\hline
\end{tabular}

Egyptian J. Desert Res., 68, No. 1, 89-116 (2018) 


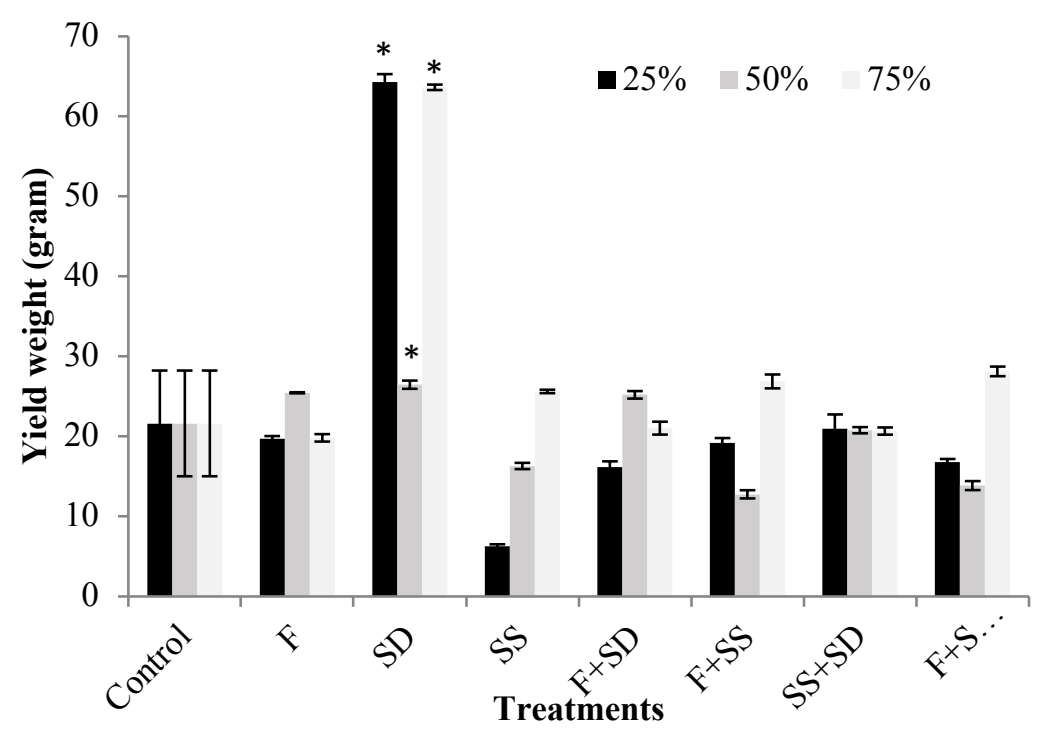

Fig. (4). Effect of compost tea treatments on yield weight of faba bean. (F) foliar spray, (SD) soil drench, (SS) seed soaking.

* Significant $(p<0.05)$

\section{Effect of Compost Tea on the Number of Leaves}

Foliar spray and SD treatments with $\mathrm{CT}$ at 25 and $75 \%$ concentrations, significantly increased number of leaves, comparing with control (Table 4 and Fig. 5). Makkar et al. (2017) stated that there was an indication of high photosynthetic efficiency combined with foliar application of CT. El-Sherbeny et al. (2012) mentioned that, medium CT level did not significantly increase the number of leaves of Brassica rapa (turnip) plants, compared with control. Decrement of the number of leaves with the increase of CT concentration (Fig. 5) might be due to the age of applied CT (six days), which contains several microbial metabolites beside nutrients. Some of these metabolites may act against increasing the number of leaves at high concentrations of CT. These results are in agreement with Kim et al. (2015), who revealed that, the red leaf lettuce treated with $\mathrm{F}$ spray and with higher CT concentration was less effective in increasing the number of leaves than in the lower CT concentration. Integrated treatment of SD with SS at $25 \%$ CT significantly increased the number of leaves. Several authors reported similar results. Hegazi and Algharib (2014) recorded that the number of plant leaves, improved as plants received $25 \%$ of mineral NPK $+75 \%$ of CT as a SD, but Suganthi and Jayanandhan (2015) mentioned that the SS with CT increased the number of leaves by around $43 \%$ compared with water SS as a control. Meanwhile, foliar application of CT, did not significantly affect the number of leaves per plant in tomatoes infected by powdery mildew (Segarra et al., 2009). At $15 \mathrm{~cm}^{3} /$ seedling of CT, as SD, with or without 
mineral NPK, for "Aggizi" olive seedlings under greenhouse condition, all vegetative growth, plant height increment $\%$, number of leaves/seedling and dry weight of leaves \%, all increased compared with control (Haggag et al., 2014). In contrast, Mohd Din et al. (2017) reported that the effect of compost extract on the shoots length was not significant.

Table (4). Effect of compost tea treatments and concentrations on leaves number.

\begin{tabular}{|c|c|c|c|}
\hline \multirow[t]{2}{*}{ Treatments } & & Leaves number & S.D. \\
\hline & $25 \% \mathrm{CT}$ & 44.89 & 0.70 \\
\hline \multirow[t]{3}{*}{$\mathbf{F}$} & $50 \% \mathrm{CT}$ & 28.10 & 0.58 \\
\hline & $75 \% \mathrm{CT}$ & 32.44 & 0.77 \\
\hline & Mean & 35.44 & 8.36 \\
\hline \multirow{4}{*}{ S.D } & $25 \% \mathrm{CT}$ & 36.56 & 0.20 \\
\hline & $50 \% \mathrm{CT}$ & 24.11 & 2.83 \\
\hline & $75 \% \mathrm{CT}$ & 33.22 & 1.26 \\
\hline & Mean & 31.30 & 6.44 \\
\hline \multirow{4}{*}{ S.S. } & $25 \% \mathrm{CT}$ & 15.56 & 1.17 \\
\hline & $50 \%$ CT & 18.67 & 0.66 \\
\hline & $75 \% \mathrm{CT}$ & 17.89 & 2.22 \\
\hline & Mean & 17.37 & 1.62 \\
\hline \multirow{4}{*}{ F+S.D } & $25 \% \mathrm{CT}$ & 27.11 & 1.34 \\
\hline & $50 \% \mathrm{CT}$ & 17.56 & 2.22 \\
\hline & $75 \% \mathrm{CT}$ & 17.10 & 1.53 \\
\hline & Mean & 20.89 & 5.39 \\
\hline \multirow{4}{*}{ F+S.S. } & $25 \% \mathrm{CT}$ & 23.00 & 1.46 \\
\hline & $50 \% \mathrm{CT}$ & 28.56 & 0.20 \\
\hline & $75 \% \mathrm{CT}$ & 23.44 & 1.02 \\
\hline & Mean & 25.00 & 3.09 \\
\hline \multirow{4}{*}{ S.D+S.S. } & $25 \% \mathrm{CT}$ & 32.22 & 0.77 \\
\hline & $50 \% \mathrm{CT}$ & 19.56 & 0.84 \\
\hline & $75 \% \mathrm{CT}$ & 24.67 & 1.33 \\
\hline & Mean & 25.48 & 6.37 \\
\hline \multirow{4}{*}{ F+S.D+S.S. } & $25 \% \mathrm{CT}$ & 25.22 & 2.17 \\
\hline & $50 \% \mathrm{CT}$ & 25.89 & 1.54 \\
\hline & $75 \% \mathrm{CT}$ & 17.22 & 1.07 \\
\hline & Mean & 22.78 & 4.82 \\
\hline \multicolumn{2}{|c|}{ Control } & 31.337 & 0 \\
\hline \multicolumn{2}{|c|}{ App. methods } & 0.52 & \\
\hline \multicolumn{2}{|c|}{ Concentrations } & 0.30 & \\
\hline \multicolumn{2}{|c|}{ Interaction } & 2.09 & \\
\hline
\end{tabular}

Egyptian J. Desert Res., 68, No. 1, 89-116 (2018) 


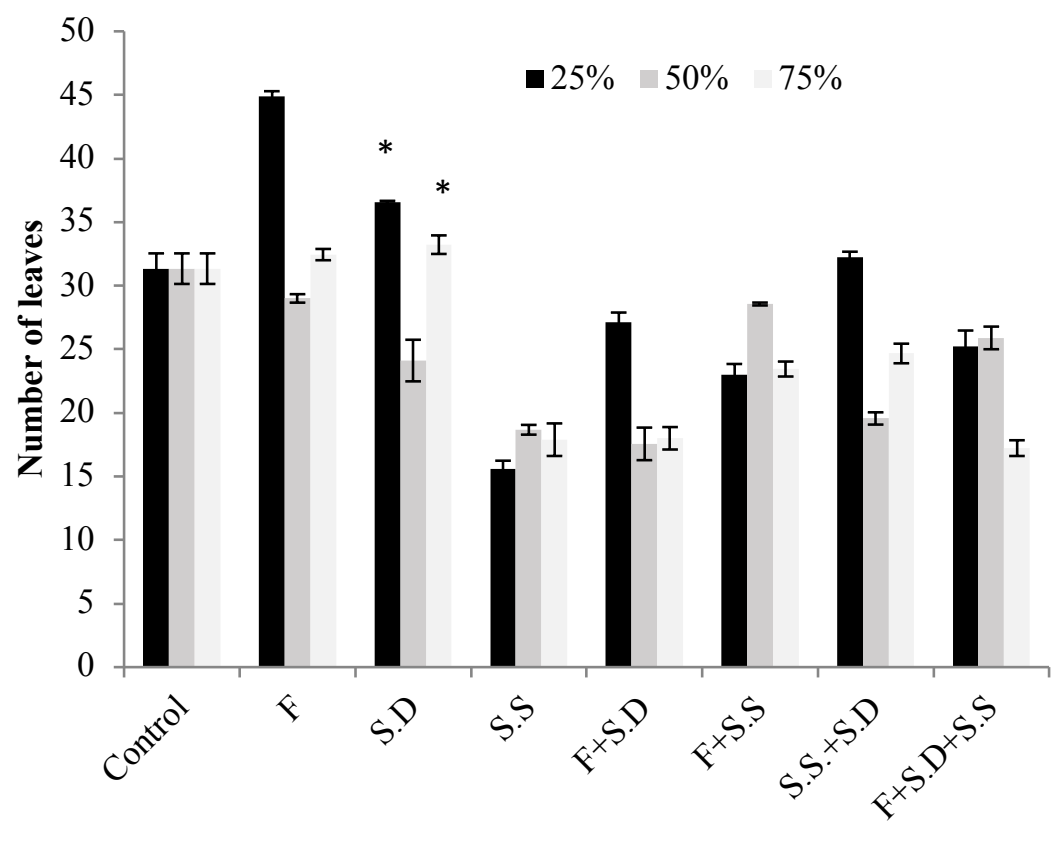

\section{Treatments}

Fig. (5). Effect of compost tea treatments on leaves number of faba bean. $(\mathrm{F})$ foliar spray, (SD) soil drench, (SS) seed soaking.

* Significant $(p<0.05)$

\section{Effect of Compost Tea on the Number of Pods}

Adding CT as a SD enhanced number of pods, significantly, compared with control (Table 5 and Fig. 6). It was about $127 \%$ at $25 \% \mathrm{SD}$ concentration. These results are in agreement with Ali (2015), who mentioned that applying CT to faba bean enhanced the number of pods per plant. In addition, integrated treatment of F, SD and SS increased the number of pods significantly, compared with control at $75 \%$ concentration. 
Table (5). Effect of compost tea treatments and concentrations on pods number.

\begin{tabular}{|c|c|c|c|c|}
\hline & \multicolumn{2}{|c|}{ Treatments } & \multirow{2}{*}{$\begin{array}{c}\begin{array}{c}\text { Pods } \\
\text { number }\end{array} \\
3.220 \\
\end{array}$} & \multirow{2}{*}{$\begin{array}{l}\text { SD } \\
0.19\end{array}$} \\
\hline & \multirow{4}{*}{$\mathbf{F}$} & $25 \% \mathrm{CT}$ & & \\
\hline & & $50 \% \mathrm{CT}$ & 3.330 & 0.00 \\
\hline & & $75 \% \mathrm{CT}$ & 3.110 & 0.19 \\
\hline & & Mean & 3.220 & 0.11 \\
\hline & \multirow{4}{*}{ SD } & $25 \% \mathrm{CT}$ & 8.333 & 0.33 \\
\hline & & $50 \% \mathrm{CT}$ & 3.670 & 0.00 \\
\hline & & $75 \% \mathrm{CT}$ & 8.333 & 0.20 \\
\hline & & Mean & 6.779 & 2.48 \\
\hline & \multirow{4}{*}{ SS } & $25 \% \mathrm{CT}$ & 1.447 & 0.39 \\
\hline & & $50 \% \mathrm{CT}$ & 2.667 & 0.36 \\
\hline & & $75 \% \mathrm{CT}$ & 3.443 & 0.20 \\
\hline & & Mean & 2.519 & 1.00 \\
\hline & \multirow{4}{*}{$\mathbf{F}+\mathbf{S D}$} & $25 \% \mathrm{CT}$ & 3.223 & 0.39 \\
\hline & & $50 \% \mathrm{CT}$ & 3.557 & 0.51 \\
\hline & & $75 \% \mathrm{CT}$ & 3.223 & 0.39 \\
\hline & & Mean & 3.334 & 0.19 \\
\hline & \multirow{4}{*}{$\mathbf{F}+\mathbf{S S}$} & $25 \% \mathrm{CT}$ & 3.557 & 0.20 \\
\hline & & $50 \% \mathrm{CT}$ & 2.553 & 0.69 \\
\hline & & $75 \% \mathrm{CT}$ & 3.667 & 0.34 \\
\hline & & Mean & 3.259 & 0.53 \\
\hline & \multirow{4}{*}{ SD+SS } & $25 \% \mathrm{CT}$ & 2.890 & 0.19 \\
\hline & & $50 \% \mathrm{CT}$ & 2.780 & 0.19 \\
\hline & & $75 \%$ CT & 2.777 & 0.51 \\
\hline & & Mean & 2.816 & 0.06 \\
\hline & \multirow{4}{*}{$\mathbf{F}+\mathbf{S D}+\mathbf{S S}$} & $25 \% \mathrm{CT}$ & 3.333 & 0.34 \\
\hline & & $50 \%$ CT & 1.890 & 0.38 \\
\hline & & $75 \%$ CT & 4.443 & 0.20 \\
\hline & & Mean & 3.222 & 1.28 \\
\hline & \multicolumn{2}{|l|}{ Control } & 3.667 & 3.14 \\
\hline & \multirow{3}{*}{\multicolumn{2}{|c|}{$\begin{array}{c}\text { App. methods } \\
\text { Concentrations } \\
\text { Interaction }\end{array}$}} & 0.110 & \\
\hline L.S.D. & & & 0.060 & \\
\hline$(5 \%)$ & & & 0.450 & \\
\hline
\end{tabular}

Egyptian J. Desert Res., 68, No. 1, 89-116 (2018) 


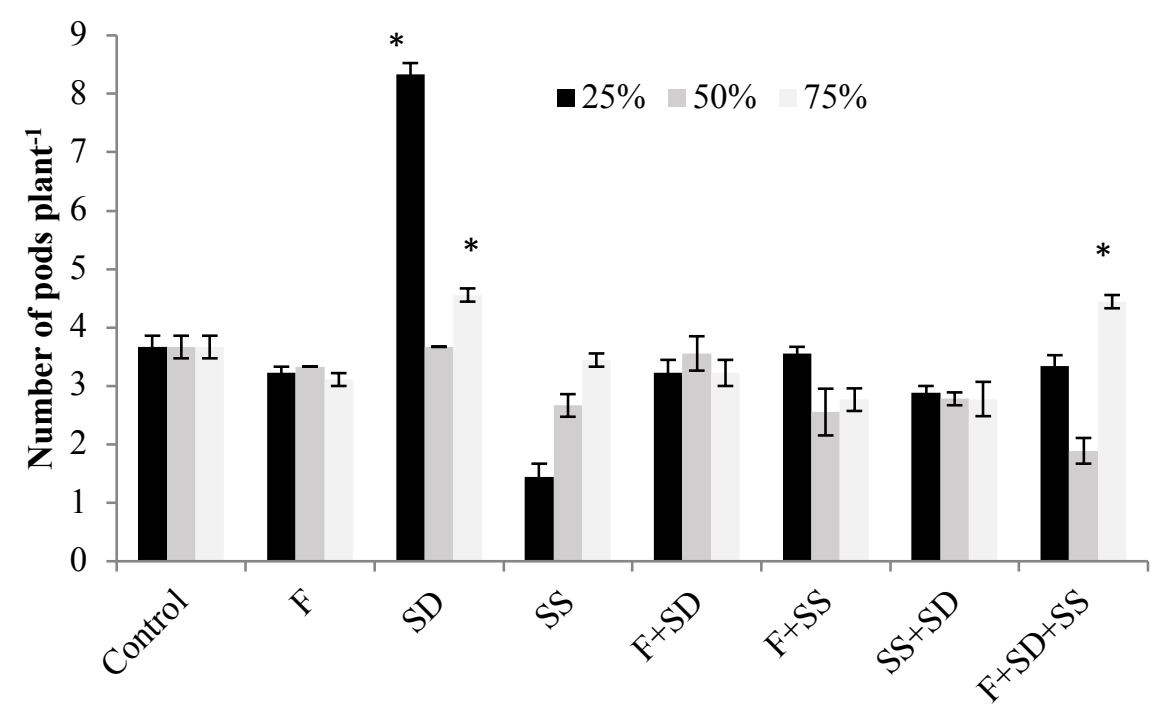

Treatments

Fig. (6). Effect of compost tea treatments on the number of pods.

(F) foliar spray, (SD) soil drench, (SS) seed soaking.

* Significant $(p<0.05)$

\section{Effect of Compost Tea on the Number and Weight of Seeds}

Application of compost as SD increased the number of seeds and weight of seeds, significantly, compared with control, (Table 5, Fig. 7 and 8 ). Seed soaking, alone or integrated with $\mathrm{F}$ or SD treatments, at $75 \%$ concentration, significantly increased the weight of seeds. Besides that, $\mathrm{F}$ when integrated with SD at 50\% concentration CT also increased the weight of seeds. The enhancement is usually due to the stimulation of growth by directly improving the nutrient availability, or indirectly by promoting the cation exchange capacity of plants (Ingham, 2005). According to Hegazi and Algharib (2014), application of CT as SD, was better than as a foliar. It has an effective role on the enhancement of plant yield components (100-seed weight) after it was added during the irrigation by SD method (Ali, 2015). SS with CT, usually, gets a healthy bunch of soil microbes coating the seed. 
Table (6). Effect of compost tea treatments and concentrations on seeds number/plant and seeds weight.

\begin{tabular}{|c|c|c|c|}
\hline \multicolumn{2}{|c|}{ Treatments } & \multirow{2}{*}{$\begin{array}{c}\begin{array}{c}\text { Seeds } \\
\text { number }\end{array} \\
5.667\end{array}$} & \multirow{2}{*}{$\begin{array}{l}\text { SD } \\
0.34\end{array}$} \\
\hline & $25 \% \mathrm{CT}$ & & \\
\hline \multirow[t]{3}{*}{$\mathbf{F}$} & $50 \% \mathrm{CT}$ & 7.670 & 1.09 \\
\hline & $75 \% \mathrm{CT}$ & 5.333 & 0.34 \\
\hline & Mean & 6.223 & 1.26 \\
\hline \multirow{4}{*}{ SD } & $25 \% \mathrm{CT}$ & 21.443 & 1.17 \\
\hline & $50 \% \mathrm{CT}$ & 8.000 & 0.33 \\
\hline & $75 \% \mathrm{CT}$ & 19.780 & 1.17 \\
\hline & Mean & 16.408 & 7.33 \\
\hline \multirow{4}{*}{ SS } & $25 \% \mathrm{CT}$ & 1.667 & 034 \\
\hline & $50 \% \mathrm{CT}$ & 5.110 & 0.38 \\
\hline & $75 \% \mathrm{CT}$ & 7.670 & 1.09 \\
\hline & Mean & 4.816 & 3.01 \\
\hline \multirow{4}{*}{$\mathbf{F}+\mathrm{SD}$} & $25 \% \mathrm{CT}$ & 3.997 & 0.58 \\
\hline & $50 \% \mathrm{CT}$ & 8.223 & 0.51 \\
\hline & $75 \% \mathrm{CT}$ & 6.443 & 0.84 \\
\hline & Mean & 6.221 & 2.12 \\
\hline \multirow{4}{*}{$\mathbf{F}+\mathbf{S S}$} & $25 \% \mathrm{CT}$ & 3.223 & 0.51 \\
\hline & $50 \% \mathrm{CT}$ & 3.443 & 0.51 \\
\hline & $75 \% \mathrm{CT}$ & 6.220 & 0.84 \\
\hline & Mean & 4.296 & 0.16 \\
\hline \multirow{4}{*}{ SD+SS } & $25 \% \mathrm{CT}$ & 6.110 & 0.38 \\
\hline & $50 \% \mathrm{CT}$ & 5.110 & 0.19 \\
\hline & $75 \% \mathrm{CT}$ & 6.000 & 0.88 \\
\hline & Mean & 5.740 & 0.55 \\
\hline \multirow{4}{*}{$\mathbf{F}+\mathbf{S D}+\mathbf{S S}$} & $25 \% \mathrm{CT}$ & 3.333 & 0.36 \\
\hline & $50 \% \mathrm{CT}$ & 2.777 & 0.51 \\
\hline & $75 \% \mathrm{CT}$ & 6.887 & 0.51 \\
\hline & Mean & 4.332 & 2.23 \\
\hline \multicolumn{2}{|l|}{ Control } & 8.220 & 0.00 \\
\hline \multicolumn{2}{|c|}{ App. methods } & 0.180 & \\
\hline \multicolumn{2}{|c|}{ Concentrations } & 0.100 & \\
\hline \multicolumn{2}{|c|}{ Interaction } & 0.710 & \\
\hline
\end{tabular}

\begin{tabular}{|c|c|c|c|}
\hline \multicolumn{2}{|c|}{ Treatments } & $\begin{array}{c}\text { Seeds } \\
\text { weight }\end{array}$ & SD \\
\hline \multirow{4}{*}{$\mathbf{F}$} & $25 \% \mathrm{CT}$ & 6.880 & 0.23 \\
\hline & $50 \% \mathrm{CT}$ & 6.710 & 0.86 \\
\hline & $75 \% \mathrm{CT}$ & 7.400 & 0.15 \\
\hline & Mean & 6.997 & 0.36 \\
\hline \multirow{4}{*}{ SD } & $25 \% \mathrm{CT}$ & 22.950 & 0.52 \\
\hline & $50 \% \mathrm{CT}$ & 9.667 & 0.25 \\
\hline & $75 \% \mathrm{CT}$ & 22.453 & 0.66 \\
\hline & Mean & 18.357 & 7.53 \\
\hline \multirow{4}{*}{ SS } & $25 \% \mathrm{CT}$ & 2.767 & 0.42 \\
\hline & $50 \% \mathrm{CT}$ & 6.797 & 0.34 \\
\hline & $75 \% \mathrm{CT}$ & 10.583 & 1.51 \\
\hline & Mean & 6.716 & 3.91 \\
\hline \multirow{4}{*}{$\mathbf{F}+\mathbf{S D}$} & $25 \% \mathrm{CT}$ & 6.480 & 0.44 \\
\hline & $50 \% \mathrm{CT}$ & 11.293 & 0.67 \\
\hline & $75 \% \mathrm{CT}$ & 7.703 & 0.12 \\
\hline & Mean & 8.492 & 2.50 \\
\hline \multirow{4}{*}{$\mathbf{F}+\mathbf{S S}$} & $25 \% \mathrm{CT}$ & 4.120 & 0.58 \\
\hline & $50 \% \mathrm{CT}$ & 5.117 & 0.31 \\
\hline & $75 \% \mathrm{CT}$ & 10.317 & 1.46 \\
\hline & Mean & 6.518 & 3.33 \\
\hline \multirow{4}{*}{ SD+SS } & $25 \% \mathrm{CT}$ & 7.580 & 0.32 \\
\hline & $50 \% \mathrm{CT}$ & 7.343 & 0.66 \\
\hline & $75 \% \mathrm{CT}$ & 9.947 & 0.05 \\
\hline & Mean & 8.290 & 1.44 \\
\hline \multirow{4}{*}{$\mathbf{F}+\mathbf{S D}+\mathbf{S S}$} & $25 \% \mathrm{CT}$ & 5.083 & 0.31 \\
\hline & $50 \% \mathrm{CT}$ & 4.980 & 1.16 \\
\hline & $75 \% \mathrm{CT}$ & 7.857 & 0.77 \\
\hline & Mean & 5.973 & 1.36 \\
\hline \multicolumn{2}{|c|}{ Control } & 9.520 & 0.00 \\
\hline & 0.240 & \\
\hline & & 0.130 & \\
\hline \multicolumn{2}{|c|}{$\begin{array}{l}\text { Concentrations } \\
\text { Interaction }\end{array}$} & 0.940 & \\
\hline
\end{tabular}




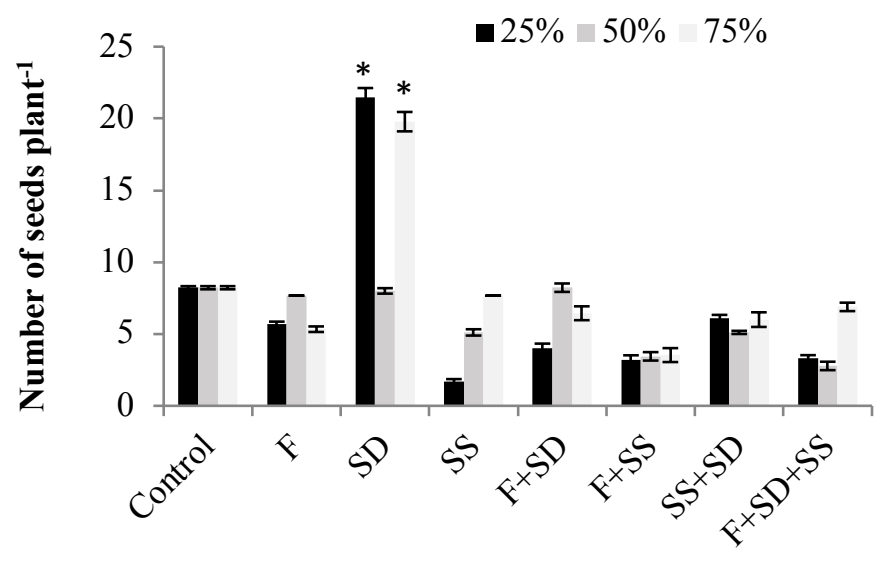

Treatments

Fig. (7). Effect of compost tea on the number of seeds. (F) foliar spray, (SD) soil drench, (SS) seed soaking. * Significant $(p<0.05)$

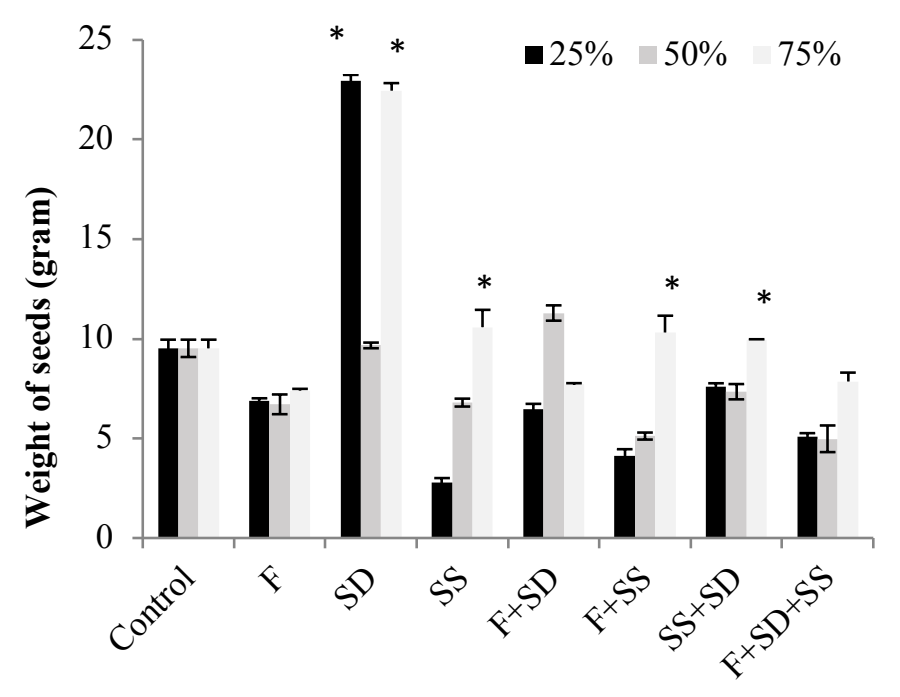

Treatments

Fig. (8). Effect of compost tea treatments on the weight of seeds (F) foliar spray, (SD) soil drench, (SS) seed soaking.

* Significant $(p<0.05)$ 


\section{Effect of Compost Tea Treatments on Soil Microorganisms}

Adding CT significantly increased soil microorganisms in all application methods compared with the control (Table 7 and Fig. 9). Foliar spray was the most significantly effective on soil microorganisms compared with other methods. This approach reveals that CT contains long chain carbon molecules that provide carbon and oxygen for soil microorganisms (Grobe, 1997). Compost tea naturally occurring microorganisms might have the opportunity to become a part of the soil and rhizosphere microbial community (Bess, 2000). The total microbial count was $676.7 \times 103$, with $25 \%$ CT (Fig. 9). Foliar spray with CT allows nutrients to be absorbed by the plants directly through stomata on their leaf surfaces. In our experiments CT age (six days), which was mainly effective for disease suppression, might be, was not loaded enough with nutrients as normally used fresh CT, because of the microbial growth rates and nutrients consumed by microorganisms. Therefore, direct absorption by leaf surface was more effective in root zone and microbial community in rhizosphere. Spraying of CT led to a positive effect on N, P and K concentrations uptakes, (Abd El-Hameed, 2008). Microorganisms' different populations were greater in the treatments of CT, and increased with time as well (Taha et al., 2016). These factors affecting soil microorganisms with consideration of CT age (six days old), concentration and application method. On the other hand, the highest values coming from foliar application compared with other application methods may refer to the age of $\mathrm{CT}$ that inhibit the pathogen and decrease disease severity the most by foliar application as mentioned before.

\section{Effect of Compost Tea on Oxidative Enzymes Activities}

All plants possess resistant mechanisms. Oxidative enzymes have a role in the defensive reactions of infected plants. Enzymes responsible for induction of resistance in plants include (PO) and (PPO). Thus, attention has been given to them. In this study, PO increased by around $200 \%$, compared with control, with all CT treatments, with almost no difference among treatments (Fig. 10). Polyphenol oxidase enzyme in faba bean leaves increased by $1411 \%$ (Fig. 11) by integrated treatment with F, SD and SS at $50 \%$ CT concentration. While increased $811 \%$ with SS treatment at $75 \% \mathrm{CT}$ concentration. Moreover, $760 \%$ and $714 \%$ with $\mathrm{F}$ and SS and foliar treatments respectively at $25 \% \mathrm{CT}$ concentration. Soil drench treatment decreased the enzyme activity when applied alone or integrated with F or F and SS as shown in Fig. (11).

Egyptian J. Desert Res., 68, No. 1, 89-116 (2018) 
Table (7). Effect of compost tea treatments and concentrations on soil microorganisms.

\begin{tabular}{|c|c|c|c|c|}
\hline & \multicolumn{2}{|l|}{ Treatments } & \multirow{2}{*}{$\frac{\text { CFU*1000 }}{676.67}$} & \multirow{2}{*}{$\begin{array}{c}\text { SD } \\
228.98\end{array}$} \\
\hline \multirow{4}{*}{\multicolumn{2}{|c|}{$\mathbf{F}$}} & $25 \% \mathrm{CT}$ & & \\
\hline & & $50 \% \mathrm{CT}$ & 84.67 & 16.17 \\
\hline & & $75 \% \mathrm{CT}$ & 170.00 & 26.46 \\
\hline & & Mean & 310.44 & 320.01 \\
\hline \multirow{4}{*}{\multicolumn{2}{|c|}{ SD }} & $25 \% \mathrm{CT}$ & 46.67 & 10.41 \\
\hline & & $50 \% \mathrm{CT}$ & 323.33 & 158.85 \\
\hline & & $75 \% \mathrm{CT}$ & 5.67 & 2.89 \\
\hline & & Mean & 125.22 & 172.79 \\
\hline \multirow{4}{*}{\multicolumn{2}{|c|}{ SS }} & $25 \% \mathrm{CT}$ & 59.33 & 9.24 \\
\hline & & $50 \% \mathrm{CT}$ & 114.33 & 7.77 \\
\hline & & $75 \% \mathrm{CT}$ & 108.67 & 10.26 \\
\hline & & Mean & 94.11 & 30.25 \\
\hline \multirow{4}{*}{\multicolumn{2}{|c|}{$\mathbf{F}+\mathbf{S D}$}} & $25 \% \mathrm{CT}$ & 357.33 & 40.50 \\
\hline & & $50 \% \mathrm{CT}$ & 143.00 & 18.36 \\
\hline & & $75 \% \mathrm{CT}$ & 41.00 & 12.29 \\
\hline & & Mean & 180.44 & 161.46 \\
\hline \multirow{4}{*}{\multicolumn{2}{|c|}{$\mathbf{F}+\mathbf{S S}$}} & $25 \% \mathrm{CT}$ & 352.33 & 11.37 \\
\hline & & $50 \% \mathrm{CT}$ & 91.00 & 18.33 \\
\hline & & $75 \% \mathrm{CT}$ & 242.67 & 46.69 \\
\hline & & Mean & 228.67 & 131.23 \\
\hline \multirow{4}{*}{\multicolumn{2}{|c|}{ SD+SS }} & $25 \% \mathrm{CT}$ & 226.67 & 31.56 \\
\hline & & $50 \% \mathrm{CT}$ & 181.33 & 17.24 \\
\hline & & $75 \% \mathrm{CT}$ & 114.67 & 25.32 \\
\hline & & Mean & 174.22 & 56.34 \\
\hline \multirow{4}{*}{\multicolumn{2}{|c|}{$\mathbf{F}+\mathbf{S D}+\mathbf{S S}$}} & $25 \% \mathrm{CT}$ & 281.67 & 118.93 \\
\hline & & $50 \% \mathrm{CT}$ & 76.67 & 13.58 \\
\hline & & $75 \% \mathrm{CT}$ & 143.67 & 30.66 \\
\hline & & Mean & 167.33 & 104.53 \\
\hline \multicolumn{3}{|c|}{ Control } & 40.30 & 0.00 \\
\hline \multirow{3}{*}{$\begin{array}{l}\text { L.S.D. } \\
(5 \%)\end{array}$} & \multirow{3}{*}{\multicolumn{2}{|c|}{$\begin{array}{l}\text { App. methods } \\
\text { Concentrations } \\
\text { Interaction }\end{array}$}} & 30.04 & \\
\hline & & & 17.17 & \\
\hline & & & 120.15 & \\
\hline
\end{tabular}

Egyptian J. Desert Res., 68, No. 1, 89-116 (2018) 


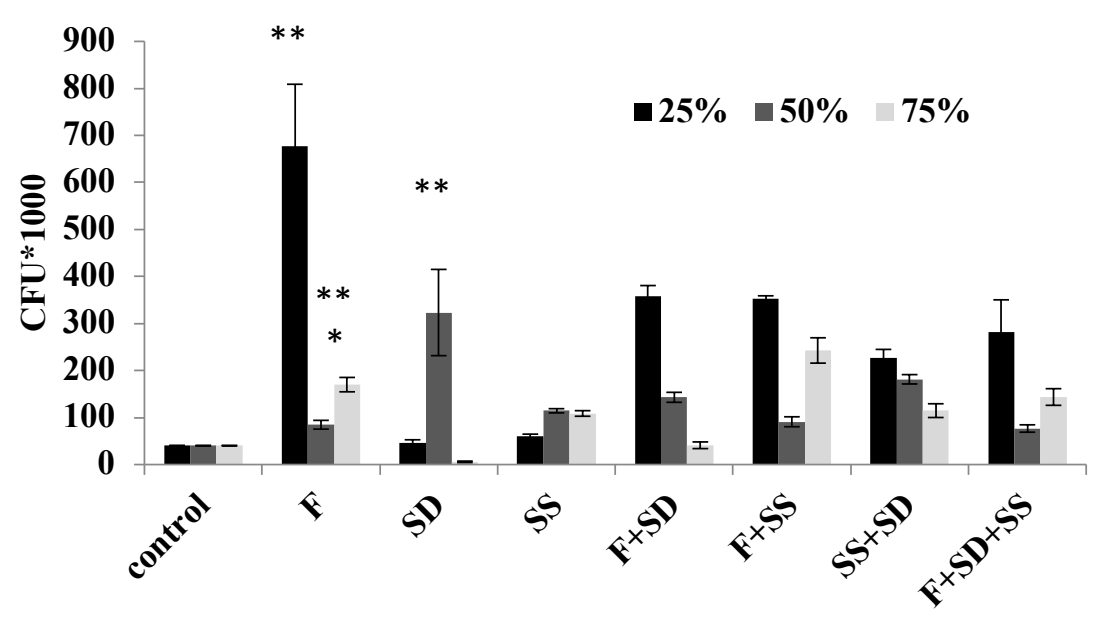

Tratments

Fig. (9). Effect of compost tea treatments on the total microbial count of soil (F) foliar spray, (SD) soil drench, (SS) seed soaking.

**Most significant $(p<0.01)$

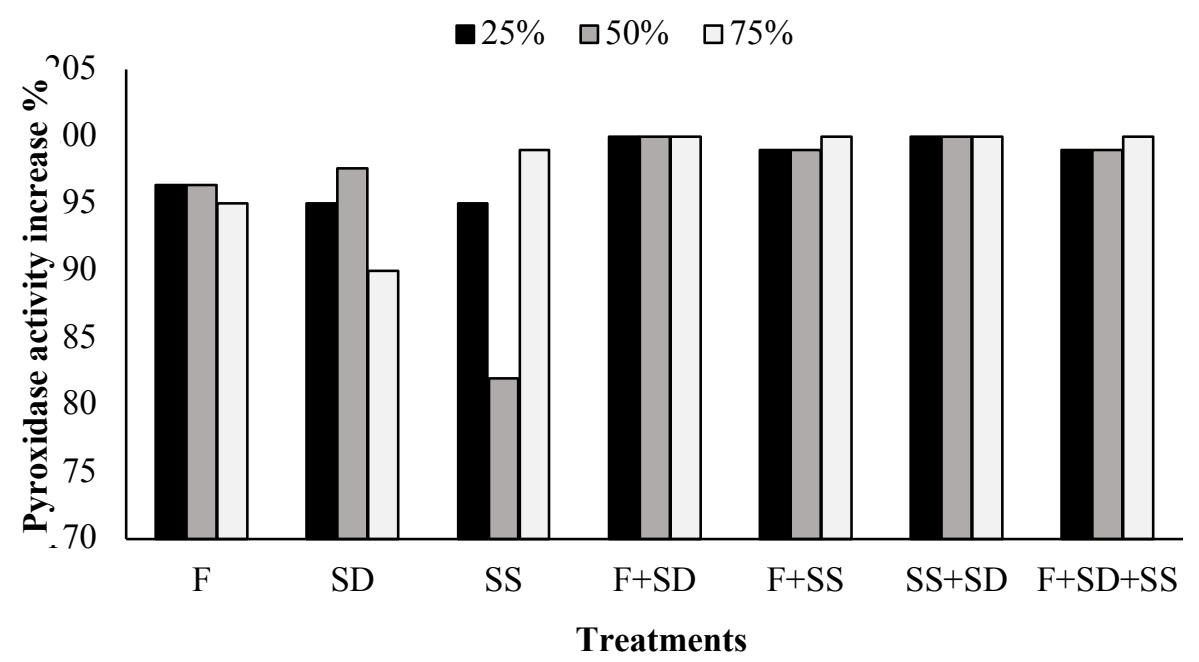

Fig. (10). Effect of compost tea treatments on peroxidase enzyme activity. (F) foliar spray, (SD) soil drench, (SS) seed soaking.

Egyptian J. Desert Res., 68, No. 1, 89-116 (2018) 


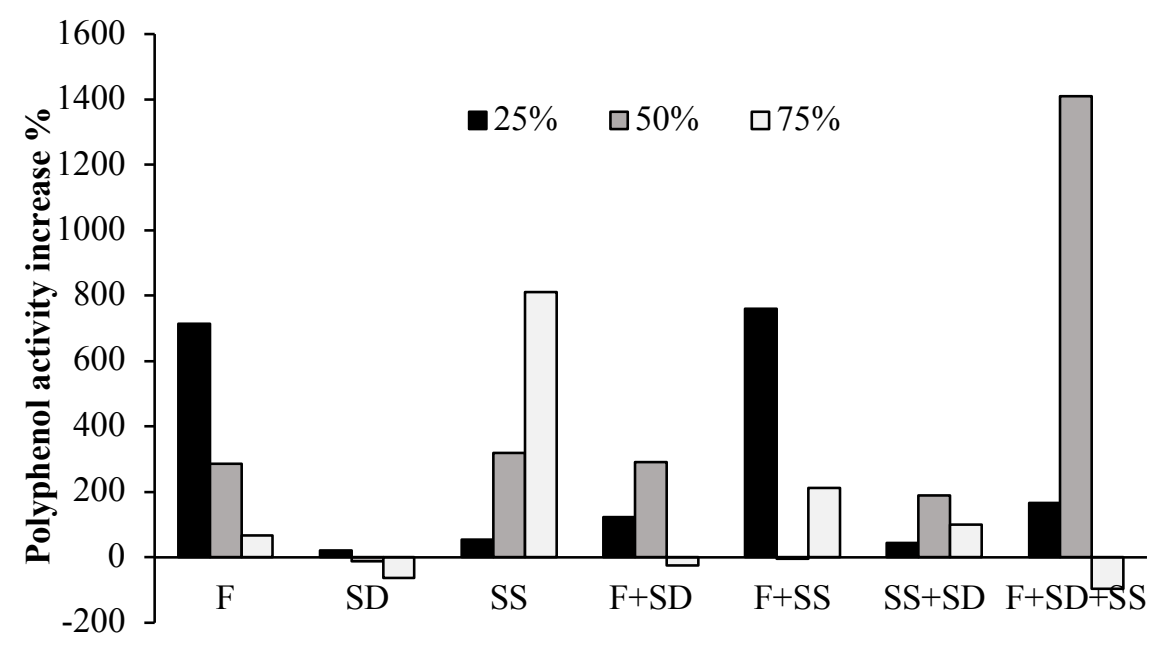

Treatments

Fig. (11). Effect of compost tea treatments on polyphenol oxidase enzyme activity.

(F) foliar spray, (SD) soil drench, (SS) seed soaking.

Goldstein (1998) reported that compost extracts activate diseaseresistant genes in plants, in response to the presence of pathogen; they mobilize chemical defense against the pathogen invasion. Activity of inducible enzymes such as PO and PPO were increased in infected okra plants pretreated with CT. The induction increments were observed in the early phase of infection (Siddiqui et al., 2009). Both of PPO and PO enzymes are responsible for phenolic compounds oxidation into antimicrobial quinones. In plant cells infected by phytopathogens, these conferring disease resistance during incompatibility reactions (Chittoor et al., 1999). Moreover, Kazan et al. (1998) added that, PO induction was a consequence of the biological and chemical activities of the CT. The importance of PO activity in disease resistance might be due to its ability to oxidize phenolic compounds to quinones, which are more toxic to pathogen than the original phenolics. On other hand, Segarra et al. (2009) reported that PO was not activated when CT was applied to foliage. He regarded this lack of response in the plant due to a priming effect, since plant defenses would only be activated by the further presence of the pathogen. In this case, the effects of CT could be comparable with the effects of beneficial microorganisms in the induction of plant resistance (ISR) by priming. 


\section{Effect of Compost Tea on Total Phenols}

Phenolic compounds are produced by plants and microorganisms, with variation among and within species. Organisms synthesize phenolic compounds as a response to ecological pressures such as pathogen and insect attack, UV radiation and wounding. Secondary metabolite antioxidants such as phenolics, in plants may provide protection against a number of diseases (Gülçin, 2012). Total phenols were enhanced by about $120 \%$, by CT as SD at $25 \%$ concentration. It reached about $61 \%$ with SD treatment integrated with $\mathrm{F}$ and SS treatments at 50\% concentration, compared with control, as revealed by Fig. (12). These results could be discussed in light of the findings of Estiarte et al. (1994), who suggested that, defensive properties including phenolics were formed in a greater concentration at low nitrogen content (nutrient stress). Synthesis of high phenolic compounds initiated by the key enzyme, phenylalanine ammonia lyase (PAL) correlated to these stress biotic factors (Naoumkina et al., 2010 and Sarma et al., 2015). These properties increased when the root absorbed more organic nutrients, as a result of the root-rhizosphere induction (Shen et al., 2013). By 10\% CT treatment as SD, total phenols increased over $62 \%$ greater than control in pepino fruit (Javanmardi and Hasanshahian, 2014). The rest of results can be discussed by the findings of Pant et al. (2009), who revealed that CT-treated pak cho plants had lower total phenolics compared with control plants. The significant positive effect on total phenolics compared with the control was under chemical fertilization. Many reports have demonstrated the beneficial effect of compost extracts, but the influence on phenolic content and antioxidant properties is still lacking. (Mohd Din et al., 2017).

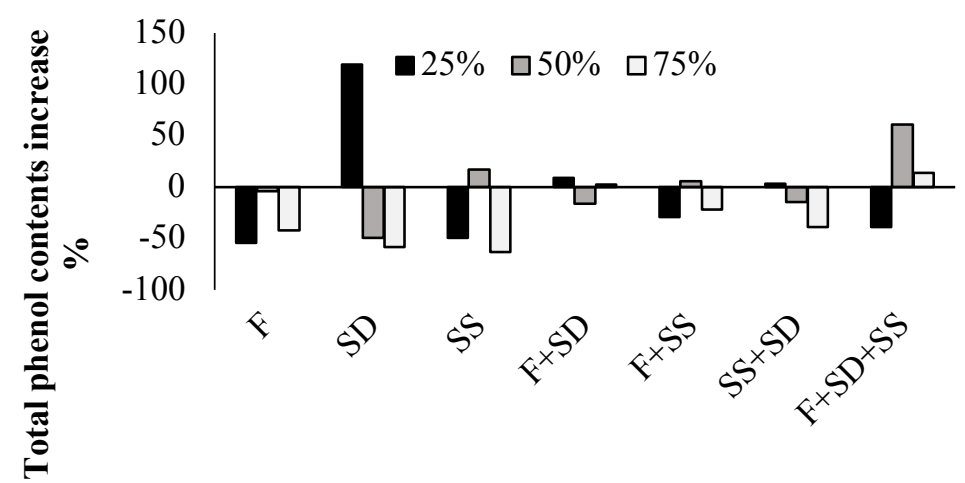

Treatments

Fig. (12). Effect of compost tea treatments on total phenols. (F) foliar spray, (SD) soil drench, (SS) seed soaking. 


\section{CONCLUSION}

This study clearly demonstrated that the application of compost tea on chocolate leaf spot disease in broad bean ( $V . f a b a)$, decreased diseases severity significantly by almost $60 \%$ with foliar application, and $50 \%$ by soil drenching, while SS increased disease severity. El-Sayed (2017) revealed that using commercial fungicides (Fungicop, Tridex and Oxydor), as a foliar before inoculation, in pots, against chocolate spot caused B. fabae decreased diseases severity by $89.2,90.4$ and $96 \%$, respectively. The number of pods increased by about 26 to $37 \%$ (soil drench with compost tea increased number of pods by about $127 \%$ with only $25 \%$ compost tea concentration). At the same time, compost tea improved growth parameters, oxidative enzymes, phenol contents and soil fertility. Soil drenching significantly increased yield weight, number of leaves, number of pods, weight of seeds and number of seeds. Soil microorganisms were enhanced significantly with foliar spray treatment. Peroxidase enzyme increased by $200 \%$ by all methods. Polyphenol oxidase enzymes reached $1411 \%$ with foliar application at $50 \%$. Total phenols reached $120 \%$ by soil drenching at $25 \%$.

From the practical point of view, compost tea could be suggested as an eco-friendly strategy that could control leaf spot disease in broad bean and reduced the chemical-based fungicide dependency with no negative effect on soil microbes.

\section{ACKNOWLEDGMENT}

The author would like to express her deepest appreciation to Dr. Ibrahim El-Fiki, Department of Plant Pathology, Faculty of Agriculture, Benha University, Egypt, for his great help to complete this work.

\section{REFERENCES}

Abd El-Hameed, K.A. (2008). Impact of including straw in preparing compost tea for organic farming. M.Sc. Thesis, Fac. of Agric., Mansoura Univ., Egypt.

Ali, O.A. (2015). Role of humic substances and compost tea in improvement of endogenous hormones content, flowering and yield and its components of faba bean (Vicia faba L.). Annals of Agric. Sci., Moshtohor, 53 (3): 373-384.

Al-Mughrabi, K.I. (2007). Suppression of Phytophthora infestans in potatoes by foliar application of food nutrients and compost tea. Aust. J. Basic Appl. Sci., 1: 785-792.

Al-Mughrabi, K.I., C. Berthélémé, T. Livingston, A. Burgoyne, R. Poirier and A.Vikram (2008). Aerobic compost tea, compost and a combination of both reduce the severity of common scab (Streptomyces scabiei) on potato tubers. J. Plant Sci., 3: 168-175. 
Baker, K. and R.J. Cook (1974). In: "Biological Control of Plant Pathogens". WH Freeman and Company, San Francisco, CA.

Bernier, C.C., S.B. Hanounik, M.M. Hussein and H.A. Mohamed (1993). Field manual of common faba bean diseases in the Nile Valley. Aleppo: International Center for Agricultural Research in the Dry Areas (ICARDA). Information Bulletin No. 3.

Bess, V.H. (2000). Understanding compost tea. Biocycle, 41(10): 71-72.

Chance, B. and A.C. Maehly (1955). Assay of Catalases and Peroxidases. In: "Methods Enzymo". Academic Press, New York, pp. 764-768.

Chittoor, J.M., J.E. Leach and F.F. White (1999). Induction of Peroxidase During Defense Against Pathogens. Datta, S.K. and S. Muthukrishnan (eds.), In: "Pathogenesis-related Proteins in Plants". CRC, Boca Raton, FL, pp.171-193.

Daoubi, M., R. Hernandez-Galan, A. Benharref and I.G. Collado (2005). Screening study of lead compounds for natural product-based fungicides: antifungal activity and biotransformation of 6 alpha, 7 alpha-dihydroxy-betahimachalene by Botrytis cinerea. J. Agric. Food Chem., 53: 6673-6677.

Eisa, A. Nawal, G.M. El-Habbaa, S.M. Omar (2006). Efficacy of antagonists, natural plant extracts and fungicides in controlling wilt, root rot and chocolate spot pathogens of faba bean in vitro. Ann. Agric. Sci., Moshtohor, 44 (4): 1547-1570.

El Hanafi, S.K. (2005). Compost tea effects on soil fertility and plant growth of organic tomato (Solanum lycopersicum Mill) in comparison with different organic fertilizers. Doctoral dissertation, IAMB Mediterranean Agronomic Institute of Bari.

El-Sayed, S.A. (2017). Efficiency of some antioxidants, biocontrol agents and fungicides in induction of faba bean resistance to chocolate spot disease. SF J. Mycology, 1 (1): 10-13.

El-Sherbeny, S.E., S.F. Hendawy, A.A.Youssef, N.Y. Naguib and M.S. Hussein (2012). Response of turnip (Brassica rapa) plants to minerals or organic fertilizers treatments. JASR, 8 (2): 628-34.

Estiarte, M., I. Filella, J. Serra and J. Pefiuelas (1994). Effects of nutrient and water stress on leaf phenolic content of peppers and susceptibility to generalist herbivore Helicoverpa armigera (Hubner). Oecologia, 99: 387-391.

Essah, S.Y., R.D. Davidson and A. Houser (2013). Effect of nitrogen rate and fungicide or compost tea application on tuber yield and quality of potato cultivars. Crop Research, 46: 169-173.

Goldstein, J. (1998). Compost suppresses disease in the lab and on the fields. Biocycle, 39: 62-64.

Grobe, K. (1997). It's a new era for farm compost. Biocycle, 38 (5): 52.

Egyptian J. Desert Res., 68, No. 1, 89-116 (2018) 
Gross, A., R. Arusi and A. Nejidat (2007). Assessment of extraction methods with fowl manure for the production of liquid organic fertilizers. Bioresour. Technol., 99: 327-334.

Gülçin, I. (2012). Antioxidant activity of food constituents: an overview. Arch. Toxicol., 86 (3): 345-391.

Haggag, F. Laila, M.A. Merwad, M.F.M. Shahin, E.M. Hoballah and H.A. Mahdy (2014). Influence of mineral NPK and compost tea as soil applications on growth of "Aggizi" olive seedlings under greenhouse condition. Middle East J. Agric. Res., 3: 701-706.

Hegazi, A.Z. and A.M. Alghero (2014). Utilizing compost tea as a nutrient amendment in open filed cowpea seed production system. JBES, 5 (2): 318-328.

Hornby, D. (1983). Suppressive soils. Annu. Rev. Phytopathol., 21(1):6585.

Hsiang, T. and L. Tian (2007). Compost tea for control of dollar spot. Department of Environmental Biology, University of Guelph-GTI Annual Research Report.

Ibrahim, A.K. Heba (2008). Recycling of some agricultural and agroindustrial organic wastes through microbial activity. Dissertation, Cairo University.

Ingham, E.R. (2005). In: "The Compost Tea Brewing Manual". $5^{\text {th }}$ Ed., Soil Foodweb Inc., Corvallis, Oregon.

Islam, M.R., C. Mondal, I. Hossain and M.B. Meah (2013). Organic management: an alternative to control late blight of potato and tomato caused by Phytophthora infestans. Int. J. Theor. Appl. Sci., 5 (2): 3242.

Javanmardi, J. and O. Hasanshahian. (2014). Humic acid and manure tea affected reproductive stage and fruit quality factors of pepino in organic production system. Building Organic Bridges, 3: 683-686.

Kazan, K., K.C. Goulter, H.M. Way and J.M. Manners (1998). Expression of a pathogenesis-related peroxidase of Stylosanthes humilis in transgenic tobacco and canola and its effect on disease development. Plant Sci.,136 (2): 207-217.

Kim M.J, C.K. Shim, Y.K. Kim, S.J. Hong, J.H. Park, E.J. Han, J.H. Kim and S.C. Kim (2015). Effect of aerated compost tea on the growth promotion of lettuce, soybean and sweet corn in organic cultivation. Plant Pathol. J., 31: 259-268.

Mahmoud, M.A., S.A. Al-Sohaibani, R.M. Al-Othman, R.M. and Abeer Abd ElAziz (2012). Biochemical screening of chocolate spot disease on faba bean caused by Botrytis fabae. African J. Microbiol. Research, 6 (32): 6122-6129.

Makkar, C., J. Singh and C. Parkash (2017). Vermicompost and vermiwash as supplement to improve seedling, plant growth and yield in Linum 
usitassimum L. for organic agriculture. Int. J. Recycl. Org. Waste Agric., 6 (3): 203-218.

McGrath, M.T. (2007). Evaluation of treatments for managing foliar diseases in organically-produced tomato. Second International Symposium on Tomato Diseases, 808: 137-142.

Mohd Din, A.J., K.K. Cheng and M.R. Sarmidi (2017). Assessment of compost extract on yield and phytochemical contents of pak choi (Brassica rapa cv. chinensis) grown under different fertilizer strategies. Commun. Soil Sci. Plant Anal., 48 (3): 274-284.

Naoumkina, M.A., Q.A. Zhao, L. Gallego-Giraldo, X.B. Dai, P.X. Zhao and R.A. Dixon (2010). Genome-wide analysis of phenylpropanoid defence pathways. Mol. Plant Pathol., 11: 829-846.

On, A.N., F. Wong, Q. Ko, R.J. Tweddell, H. Antoun and T.J. Avis (2015). Antifungal effects of compost tea microorganisms on tomato pathogens. Biol. Control, 80: 63-69.

Pant, A.P., T.J. Radovich, N.V. Hue, S.T. Talcott and K.A. Krenek (2009). Vermicompost extracts influence growth, mineral nutrients, phytonutrients and antioxidant activity in pak choi (Brassica rapa $\mathrm{cv}$. bonsai, Chinensis group) grown under vermicompost and chemical fertilizer. J. Sci. Food Agric., 89 (14): 2383-2392.

Patra, H.K. and D. Mishra (1979). Pyrophosphatase, peroxidase and polyphenoloxidase activities during leaf development and senescence. Plant Physiol., 63: 318-323.

Price, M.L. and N. Duddles (1984). Chicken manure tea. Research report. Echo. Technical. Note, pp. 1-4.

Sarma, B.K., S.K. Yadav, S. Singh and H.B. Singh (2015). Microbial consortium-meadiated plant defense against phytopathogens: readdressing for enhancing efficacy. Soil Biol. Biochem., 87: 25-33.

Segarra, G., M. Reis, E. Casanova and M.I. Trillas (2009). Control of powdery mildew (Erysiphe polygoni) in tomato by foliar applications of compost tea. J. Plant Pathol., 91 (3): 683-689.

Seddigh, S. and L. Kiani (2018). Evaluation of different types of compost tea to control rose powdery mildew (Sphaerotheca pannosa var. rosae). Int. J. Pest Manage., 64 (2):1-7.

Shen, J., C. Li, G. Mi, L. Li, Y. Yuan, R. Jiang and F. Zhang (2013). Maximizing root/rhizosphere efficiency to improve crop productivity and nutrient use efficiency in intensive agriculture of China. J. Exp. Bot., 64: 1181-1192.

Siddiqui, Y., S. Meon, R. Ismail and M. Rahmani (2009). Bio-potential of compost tea from agro-waste to suppress Choanephora cucurbitarum L. the causal pathogen of wet rot of okra. Biol. Control, 49: 38-44.

Simons, T.O. and A.F. Ross (1971). Changes in phenol metabolism associated with induced systemic resistance to tobacco mosaic virus in Sumsun NN Tobacco. Phytopathology, 61 (10): 1261-1265.

Egyptian J. Desert Res., 68, No. 1, 89-116 (2018) 
Suganthi, A. and D. Jayanandhan (2015). Effect of tea compost on the growth of Vigna radiate (L.) R. Wilczek. IJAR, 1(12): 968-972.

Taha, M., A. Salama, M. El-Seedy, I. El-Akhdar, M.S. Islam, C. Barutcular and A. El Sabagh (2016). Potential impact of compost tea on soil microbial properties and performance of radish plant under sandy soil conditions - greenhouse experiments. Aust. J. Basic Appl. Sci., 10 (8): 158-165.

Taneja, S.R. and R.C. Sachar (1974). Separate monophenolase and odiphenolase enzymes in Triticum aestivum. Phytochemistry, 13: $1367-1371$.

Weltzien, H.C. (1991). Biocontrol of Foliar Fungal Disease with Compost Extracts. In: "Microbial Ecology of Leaves". Springer, New York, pp. 430-450.

Zaker, M. (2016). Natural plant products as eco-friendly fungicides for plant diseases control - A Review. The Agriculturists, 14 (1):134-141. 


\title{
أثر إستخدام شاي الكمبوست في مقاومة مرض التبقع الثيكولاتي وكثافة ميكروبات التربة لنبات الفول البلاي
}

\author{
هبة أحمد خليل إبراهيم \\ قسم خصوبة وميكروبيولوجيم إيراهيم الأراضي، مركز بحوث الصحر اء، المطرية، القاهرة، مصر

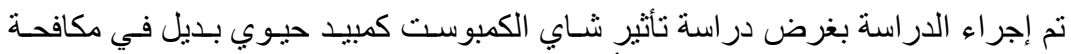

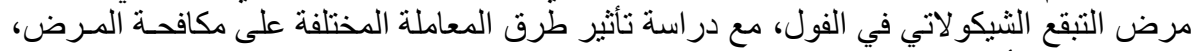

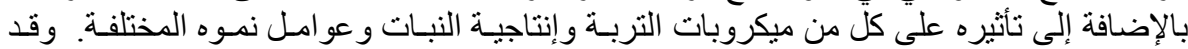

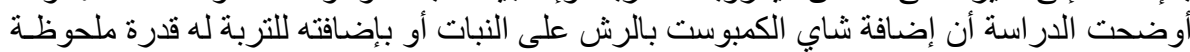

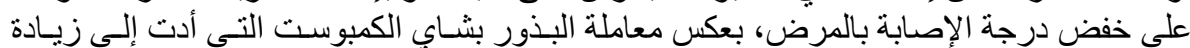

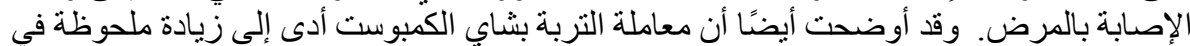

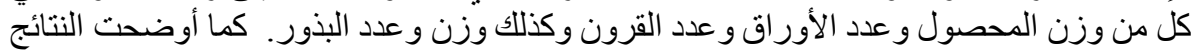

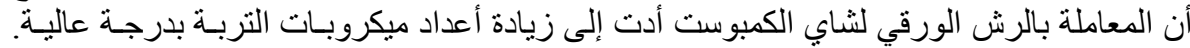

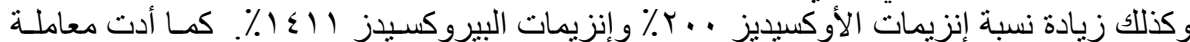

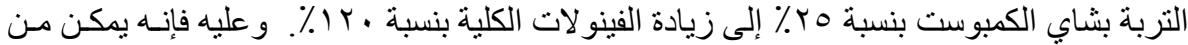

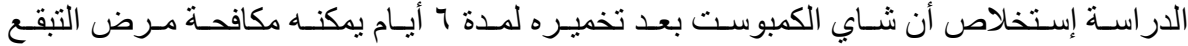

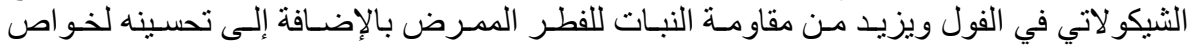 \\ المحصول بالإضافة إلى زيادة خصوبة التربة التبات
}

Egyptian J. Desert Res., 68, No. 1, 89-116 (2018) 